\title{
Association between dairy product intake and abdominal obesity in Azorean adolescents
}

\author{
S Abreu1, R Santos1, C Moreira1, S Vale1, PC Santos1,2, L Soares-Miranda1, Al Marques1, J Mota1 and P \\ Moreira1,3,4 \\ ${ }_{1}$ Research Centre in Physical Activity, Health and Leisure, Faculty of Sport, University of Porto, Porto, Portugal; \\ 2Department of Physical Therapy, School of Health Technology of Porto, Polytechnic Institute of Porto, Vila Nova de Gaia, Portugal; 3 Faculty \\ of Nutrition and Food Science, University of Porto, Porto, Portugal \\ 4Institute of Public Health, University of Porto, Porto, Portugal. Correspondence: Dr S Abreu, Research Centre in Physical Activity, Health \\ and Leisure, Faculty of Sport, University of Porto, Rua Dr Plácido Costa 91, Porto 4200.450, Portugal.
}

BACKGROUND: Some studies have reported an inverse association between dairy product (DP) consumption and weight or fat mass loss.

OBJECTIVES: The objective of our study was to assess the association between DP intake and abdominal obesity (AO) among Azorean adolescents.

SUBJECTS/METHODS: This study was a cross-sectional analysis. A total of 903 adolescents (370 boys) aged 15--16 years was evaluated. Anthropometric measurements were collected (weight, height and waist circumference (WC)) and McCarthy's cut-points were used to categorize WC. AO was defined when WC was X90th percentile. Adolescent food intake was assessed using a self-administered semiquantitative food frequency questionnaire and DP intake was categorized in 02 and X2 servings/day. Data were analyzed separately for girls and boys, and logistical regression was used to estimate the association between DPs and $\mathrm{AO}$ adjusting for potential confounders.

RESULTS: The prevalence of AO was $54.9 \%$ (boys: $32.1 \%$ and girls: $70.7 \%$, Po0.001). For boys and girls, DP consumption was $2.3 \pm 1.9$ and $2.1 \pm 1.6$ servings/day ( $\mathrm{P} 1 / 40.185)$, respectively. In both genders, the proportion of adolescents with WC 090th percentile was higher among individuals who reported a dairy intake of X2 servings/day compared with those with an intake 02 servings/day (boys: $71 \%$ vs $65 \%$ and girls: $36 \%$ vs $24 \%$, Po0.05). After adjustments for confounders, two or more DP servings per day were a negative predictor of $\mathrm{AO}$ (odds ratio, $0.217 ; 95 \%$ confidence interval, 0.075 -- 0.633 ) only in boys.

CONCLUSION: We found a protective association between DP intake and AO only in boys.

Keywords: dairy products; waist circumference; adolescents

\section{INTRODUCTION}

The prevalence of abdominal obesity $(\mathrm{AO})$ among adolescents in developed countries has been increasing, as have associated complications. 1 -- 4

Primary preventions of obesity, as well as $\mathrm{AO}$, should focus on energy balance, but intake of some foods has been shown to affect the development of AO among adolescents. 5 - 7 Recently, several5,8 - 11 but not all 12,13 epidemiological studies about this topic have shown that dairy product (DP) intake is inversely related to $\mathrm{AO}$ and body fat in children and adolescents. DPs are an important source of nutrient and/or bioactive constituents such as calcium. It appears that a high-calcium diet may have a role in preventing fat accumulation by affecting adipocyte lipid metabolism, lipogenesis and lypolysis, fat oxidation and fat absorption, through genetic and non-genetic mechanisms.14 Furthermore, according to some studies, calcium from a dairy source may be more effective than other dietary sources in reducing and regulating body fat.15,16 Although, the mechanism of this DP 'anti-obesity' effect is not yet clear, it was suggested that it may be mediated by dairy components (e.g., whey protein) other than calcium.17

At the present time, consumption of milk and milk products is not considered by dietary recommendations to have a special role in weight control,18 despite some evidence from epidemiological observational and experimental studies linking dairy food consumption to obesity.7,11,13,15,19--23 Furthermore, studies examining the association between markers of AO---such as waist circumference (WC)---and DP intake among adolescents are scarce.

Hence, the aim of the present study was to assess the association between DP intake and AO among Azorean adolescents.

\section{MATERIALS AND METHODS}

\section{Sampling}

Data for the present study were derived from a longitudinal school-based study---The Azorean Physical Activity and Health Study II, which aimed to evaluate physical activity, physical fitness, overweight/obesity prevalence, dietary intake, quality of life and other health-related factors. The study was carried out in six of the nine Azorean Islands (S Miguel, Terceira, Faial,

Pico, S Jorge and Graciosa), where $95 \%$ of the Azorean population live. 24

All participants in this study were informed of its goals, and the parent or guardian of each participant provided written informed consent. The study was approved by the Faculty of Sport and the Portuguese Foundation for Science and Technology Ethics Committees; it was conducted in accordance with the World Medical Association's Helsinki Declaration for Human Studies.

The population was selected by means of proportionate stratified random sampling, taking into account location (island) and number of students, by age and sex, in each school. The estimated number of subjects needed was 1422 , but to 
prevent information loss, data were collected for 1515 adolescents. For the purpose of the study and taking into account that cutoffs used to categorize WC are available only for age under 17, we only included adolescents aged 15--16 $\left(n^{1} / 4960\right)$, from which 57 were not included due to missing information on dietary intake $\left(n^{1 / 441)}\right.$ and WC $\left(n^{1 / 416)}\right.$. Therefore, this led a total of 903 participants (370 boys). Power analysis of the final sample was calculated post hoc being higher than 0.8 for P-value 00.05. Finally, the sample was weighted in accordance with the distribution of the Azorean population in schools and to guarantee the real representativeness of each group (by age and gender).

\section{Anthropometric measures}

Body height and body weight. Body height and body weight were determined using standard anthropometric methods. Height was measured to the nearest millimeter in bare or stocking feet, with adolescents standing upright against a Holtain portable stadiometer (Crymych, Pembrokeshire, UK). Weight was measured to the nearest $0.10 \mathrm{~kg}$, with participants lightly dressed (underwear and t-shirt) and with the use of a portable digital beam scale (Tanita Inner Scan BC 532, Tokyo, Japan). Body mass index (BMI) was calculated using the ratio of weight $/$ height2 $(\mathrm{kg} / \mathrm{m} 2)$. Subjects were classified as normal weight, overweight or obese, according to age- and sex-specific cutoff points specified by the International Obesity Task Force.25

Waist circumference. WC measurements were taken midway between the tenth rib and the iliac crest and recorded to $0.1 \mathrm{~cm}$. A non-elastic flexible tape measure was used, with subjects standing erect with arms by sides, feet together and abdomen relaxed, as well as without clothing covering the waist area. Subjects were divided into two categories (o90th and X90th percentiles) according to age- and sex-specific cutoff points specified by McCarthy.26 Subjects who were in the 90th percentile or above were considered to have $\mathrm{AO} .27$

Pubertal stage. To determine pubertal stage (ranging from stage 1 to 5 ), each subject was asked to self-assess his/her stage of secondary sex characteristics. Stage of breast development in girls and genital development in boys was evaluated according to criteria outlined by Tanner and Whitehouse.28 For the purposes of the present analyses, the original 5-stage Tanner scale was collapsed into four categories: (i) stage 1 or 2; (ii) stage 3; (iii) stage 4; and (iv) stage 5.

Socio-demographic and lifestyle variables Participants answered a questionnaire that assessed several sociodemographic and lifestyle variables.

Smoking. Participants were classified as non-smokers, former smokers (individuals who had stopped smoking for at least 6 months), occasional smokers (individuals who smoked, on average, less than one cigarette a day) and current smokers (individuals who smoked at least one cigarette a day).29 Occasional smokers were recoded and combined with current smokers, due to their small sample size.

Parental education. For the present study, the highest level of parental education (measured by number of school years completed) was used as a proxy measure of socio-economic status. Participants were divided into three categories, reflecting divisions within the Portuguese educational system: mandatory or less (p9 school years), secondary (10 --12 school years) and college/university (412 school years).

\section{Dietary intake}

Dietary intake was measured via a self-administered semiquantitative food frequency questionnaire that covered the previous 12 months and included 86 food item and beverage categories, validated for Portuguese adolescents.30 This semiquantitative food frequency questionnaire was designed in accordance with criteria laid out by Willett 31 and adapted to include a variety of typical Portuguese food items. For each item, the questionnaire offered nine frequency response options, ranging from 'never' to 'six or more times per day', and measured portion size and seasonality. Any foods not listed in the questionnaire could be listed by participants in a free-response section. Energy and nutritional intake were estimated with regard to respondents' ratings of the frequency, portion and seasonality of each item, using the software Food Processor Plus (ESHA Research Inc., Salem, OR, USA). This software uses nutritional information from the United States that has been adapted for use with typical Portuguese foods and beverages.

This study considered two DPs: milk and yogurt. We used the following amounts per servings: $250 \mathrm{ml}$ for milk (whole, reduced fat and fat free) and $200 \mathrm{~g}$ for yogurt. Participants were categorized according to the new Portuguese Food Wheel guide as eating two or more servings of milk and yogurt per day or less (X2 and 02 servings/day).32 Portions of cheese per day were considered separately---that is, one serving comprised $40 \mathrm{~g}$ of cheese (cottage and cream cheese). In view of the fact that there are no recommendations for portions of cheese, the median servings of cheese (median $1 / 40.3$ serving/day) were used to categorize participants.

Calcium intake was expressed as the calcium-to-protein ratio, to offset the effects that these two nutrients have on each another and because ratio eliminates most of the portion size estimation error.33,34

\section{Physical activity}

Physical activity was assessed via a self-report questionnaires5 that had been shown to have good test -- retest reliability among Portuguese adolescents (intraclass correlation coefficient 0.92 -- 0.96).36 From this questionnaire, a summative index (range 5-- 20) was derived. Participants who reported 412.5 points were classified as active, and those who reported 12.5 points or less comprised the low-activity group.

\section{Statistical analysis}

Data was analyzed separately for girls and boys, because it was believed that sex might influence the accumulation of abdominal fat.37 Descriptive analysis showed lifestyle, socio-demographic, anthropometric and dietary characteristics of the sample by gender. All variables were tested for normality. Independent sample t-tests were performed to compare continuous variables, and the w2-test was used with categorical variables.

The Mann-- Whitney test was performed for quantitative variables when appropriate.

The association between DP intake and WC (the dependent variable) was investigated using logistical regression (multivariate models). The multivariate-adjusted models were controlled for the following potential confounders: age (in years), BMI (in $\mathrm{kg} / \mathrm{m} 2$ ), pubertal stage (reference--- stage 1 or 2 ), physical activity level (reference---low activity), energy 
intake (in kcal), calcium-to-protein ratio and dietary fiber (in g/1000 kcal). Age, BMI, energy intake, calcium-to-protein ratio and dietary fiber were entered as continuous variables. To control for possible confounding by cheese intake, we also adjusted the multivariate models for this variable (reference---00.3 serving/day). An odds ratio (OR) and a $95 \%$ interval (Cl) were computed for the X2 servings/day DPs intake category.

A P-value of 00.05 was regarded as significant. All analyses were performed using the PASW Statistic v.18 (SPSS, Chicago, IL, USA).

\section{RESULTS}

The mean age was $15.5 \pm 0.5$ years for both genders (P1/40.695).

The prevalence of overweight/obesity was $32.2 \%$ (boys: $29.3 \%$ and girls: $34.2 \%, \mathrm{P} 1 / 40.129$ ) and of $\mathrm{AO}$ was $54.9 \%$ (boys: 32.1 and girls:

$70.7 \%$, Po0.001). Descriptive data on WC and other covariates are presented in Table 1. Average BMI for both genders was higher in those who had AO (boys: $26.4 \pm 4.0 \mathrm{~kg} / \mathrm{m} 2 \mathrm{vs} 20.7 \pm 2.2 \mathrm{~kg} / \mathrm{m} 2$,

Po0.001; girls: $23.7 \pm 3.6 \mathrm{~kg} / \mathrm{m} 2$ vs $20.4 \pm 2.9 \mathrm{~kg} / \mathrm{m} 2$, Po0.001), while no significant association was found between boys and girls.

However, the percentage of adolescents who had $\mathrm{AO}$ was higher in girls $(70.7 \%$ vs $32.2 \%$, Po0.001). Boys were more active than girls

(83.7\% vs $52.3 \%$, Po0.001). Boys who had AO were less active than those with WC o90th percentile $(77.3 \%$ vs $\left.86.5 \%, \mathrm{P}^{1} / 40.027\right)$.

\begin{tabular}{|c|c|c|c|c|c|c|c|c|c|}
\hline & \multicolumn{3}{|c|}{ Boys } & \multicolumn{3}{|c|}{ Girls } & \multirow{3}{*}{$\begin{array}{c}\text { Boys } \\
\begin{array}{c}\text { Total } \\
(\mathrm{n}=370)\end{array}\end{array}$} & \multirow{3}{*}{$\begin{array}{c}\text { Girls } \\
\begin{array}{c}\text { Total } \\
(\mathrm{n}=533)\end{array}\end{array}$} & \multirow[t]{3}{*}{$\mathrm{P}$} \\
\hline & \multicolumn{2}{|c|}{$w C$} & \multirow{2}{*}{$\mathrm{p}^{\mathrm{a}, \mathrm{b}}$} & \multicolumn{2}{|c|}{$w C$} & \multirow{2}{*}{$p^{a, b}$} & & & \\
\hline & $\begin{array}{c}<P 90 \\
(n=251)\end{array}$ & $\begin{array}{c}\geqslant P 90 \\
(\mathrm{n}=119)\end{array}$ & & $\begin{array}{c}<P 90 \\
(n=156)\end{array}$ & $\begin{array}{c}\geqslant P 90 \\
(n=377)\end{array}$ & & & & \\
\hline $\mathrm{BMI}^{\mathrm{c}}\left(\mathrm{kg} / \mathrm{m}^{2}\right)$ & $20.7 \pm 2.2$ & $26.4 \pm 4.0$ & $<0.001$ & $20.4 \pm 2.9$ & $23.7 \pm 3.6$ & $<0.001$ & $22.5 \pm 3.9$ & $22.7 \pm 3.7$ & 0.119 \\
\hline \multicolumn{10}{|l|}{ Parental education (\%) } \\
\hline Mandatory or less & 52.2 & 53.4 & \multirow{3}{*}{0.465} & 51.9 & 59.6 & \multirow{3}{*}{0.252} & 52.6 & 57.3 & \multirow{3}{*}{0.213} \\
\hline Secondary & 29.3 & 33.1 & & 29.2 & 23.5 & & 30.5 & 25.1 & \\
\hline College/university & 18.5 & 13.6 & & 18.8 & 17.0 & & 16.9 & 17.5 & \\
\hline \multicolumn{10}{|l|}{ Smoking status (\%) } \\
\hline Non-smoker & 82.1 & 86.4 & \multirow{3}{*}{0.552} & 81.1 & 81.5 & \multirow{3}{*}{0.086} & 83.5 & 83.7 & \multirow{3}{*}{0.944} \\
\hline Former smoker & 5.2 & 3.4 & & 2.6 & 5.6 & & 4.6 & 4.7 & \\
\hline Current smoker & 12.7 & 10.2 & & 8.3 & 13.0 & & 11.9 & 11.6 & \\
\hline \multicolumn{10}{|l|}{ Pubertal stage (\%) } \\
\hline Stage 1 or 2 & 1.2 & 2.5 & \multirow{4}{*}{0.017} & 1.9 & 0.5 & \multirow{4}{*}{0.009} & 1.6 & 0.9 & \multirow{4}{*}{$<0.001$} \\
\hline Stage 3 & 9.6 & 16.0 & & 24.5 & 20.4 & & 21.6 & 21.6 & \\
\hline Stage 4 & 64.1 & 47.1 & & 63.2 & 57.3 & & 59.4 & 59.0 & \\
\hline Stage 5 & 25.1 & 34.5 & & 10.3 & 21.8 & & 28.1 & 18.4 & \\
\hline \multicolumn{10}{|l|}{ Physical activity (\%) } \\
\hline Low active & 13.5 & 22.7 & \multirow{2}{*}{0.027} & 48.1 & 47.7 & \multirow{2}{*}{0.944} & 16.5 & 47.8 & \multirow{2}{*}{$<0.001$} \\
\hline Active & 86.5 & 77.3 & & 51.9 & 52.3 & & 83.5 & 52.2 & \\
\hline
\end{tabular}

Energy intake and dietary characteristics for each gender are presented in Table 2. Boys' diets were higher in energy and total and saturated fats, and lower in dietary fiber and carbohydrates, compared with girls (Po0.05 for all). There was no significant difference between boys and girls with regard to dairy, calcium and protein intake.

Distribution of adolescents by DP intake category was based on WC, as indicated in Figure 1. In both genders, the proportion of adolescents with WC o90th percentile was higher among individuals who had an intake of X2 dairy servings/day, compared with those who had an intake 02 servings/day (boys:

$71 \%$ vs $65 \%$ and girls: $36 \%$ vs $24 \%$, Po 0.05 , respectively).

Multivariate-adjusted ORs for AO for DP intake are shown in Table 3. In both genders, after adjusting for demographic variables and physical activity level, intake of X2 dairy servings per day was a negative predictor of $\mathrm{AO}$ (boys: OR, 0.474, 95\% Cl, 0.238 --0.945 and girls: OR, 0.545, 95\% Cl, 0.355 -- 0.839). After adjusting also for dietary factors (model 2), only boys who had X2 servings of DPs per day had lower risk of AO (boys: OR, $0.217,95 \% \mathrm{Cl}, 0.075--0.633$ and girls: OR, $0.560,95 \% \mathrm{Cl}, 0.307--1.022$ ). A similar result was observed after adjustment for cheese intake (model 3 ).

\section{DISCUSSION}

In this study, we observed a protective association between eating two or more servings of milk and yogurt, and $\mathrm{AO}$ in boys. This association was not confounded by other lifestyle factors or nutritional variables, particularly calcium intake.

Evidence from observational studies on the relationship between consumption of DPs and AO in adolescents are limited, and most of them8,11,12,38,39 have focused on weight and body fat loss. In children and 
adolescents, few studies have reported a protective association between dairy consumption and overweight/ obesity. For instance, Moore et al.11 in a cross-sectional study, found that adolescents in the lowest category of total dairy intake had higher BMls and more subcutaneous fat. However, longitudinal studies have yielded conflicting results. Of 10 prospective cohort studies with children and adolescents reviewed by Louie,40 6 reported no significant association and 1 reported an increased risk, while 3 found a protective association between dairy consumption and the risk of being overweight/ obese.

Regarding the association between dairy consumption and $\mathrm{AO}$, one study with adolescent found that central body fat measures (i.e., WC and the sum of suprailiac and scapular skinfold thicknesses) were inversely associated with total dairy intake.5

In adults, this relationship was examined in two cross-sectional studies.41,42 However, in only one study 41 an inverse association was shown between dairy intake (milk and yogurt) and AO. In two longitudinal studies,22,37 DPs were found to be negatively associated with WC. Vergnaud et al.22 reported that milk and yogurt intake were protective against 6 -year changes in WC only in men who were initially overweight, and Halkjaer et al.37 found a protective association only in women, with a 5-year difference in

WC for high-fat dairy intake.

The literature suggested that when DPs were separated into subgroups (i.e., milk, yogurt and cheese), a significant association with AO was only seen for some.14,40 To the best of our knowledge, only one study investigated the cross-sectional relationship between 'type' of dairy and $\mathrm{AO}$ in adolescents. Bradlee et al.,5 in data from the Third National Health and Nutrition Examination Surveys (NHANES III and NHANES 1998- 2000), showed that adolescents who met the criteria for AO reported consuming significantly fewer milk servings per day. However,

\begin{tabular}{|c|c|c|c|c|c|c|c|c|c|}
\hline & \multicolumn{3}{|c|}{ Boys } & \multicolumn{3}{|c|}{ Girls } & \multirow{3}{*}{$\begin{array}{c}\text { Boys } \\
\text { Total }(n=370)\end{array}$} & \multirow{3}{*}{$\begin{array}{c}\text { Girls } \\
\text { Total }(\mathrm{n}=533)\end{array}$} & \multirow[t]{3}{*}{$P$} \\
\hline & \multicolumn{2}{|c|}{$W C$} & \multirow[t]{2}{*}{$P$} & \multicolumn{2}{|c|}{$W C$} & \multirow[t]{2}{*}{$P$} & & & \\
\hline & $\begin{array}{c}<\mathrm{P} 90 \\
(\mathrm{n}=251)\end{array}$ & $\begin{array}{c}\geqslant P 90 \\
(\mathrm{n}=119)\end{array}$ & & $\begin{array}{c}<P 90 \\
(n=156)\end{array}$ & $\begin{array}{c}\geqslant P 90 \\
(n=377)\end{array}$ & & & & \\
\hline Energy intake $e^{\mathrm{a}, \mathrm{b}}$ (kcal) & $2720 \pm 416.5$ & $2631.0 \pm 404.9$ & 0.454 & $2544.9 \pm 454.3$ & $2362.2 \pm 278.4$ & 0.087 & $2691.9 \pm 411.5$ & $2415.6 \pm 333.4$ & $<0.001$ \\
\hline $\begin{array}{l}\text { Carbohydrates } s^{a, b} \\
\text { (\% of energy) }\end{array}$ & $49.7 \pm 8.3$ & $50.2 \pm 9.2$ & 0.618 & $51.6 \pm 8.6$ & $50.7 \pm 7.8$ & 0.246 & $49.9 \pm 8.6$ & $51.0 \pm 8.0$ & 0.045 \\
\hline $\begin{array}{l}\text { Total fat } \\
\text { (\% of energy) }\end{array}$ & $33.5 \pm 5.2$ & $33.2 \pm 6.1$ & 0.647 & $32.4 \pm 6.0$ & $32.6 \pm 5.3$ & 0.755 & $33.4 \pm 5.5$ & $32.5 \pm 5.5$ & 0.025 \\
\hline $\begin{array}{l}\text { Saturated fat } \\
\text { (\% of energy) }\end{array}$ & $12.1 \pm 2.6$ & $11.6 \pm 2.5$ & 0.157 & $11.4 \pm 2.6$ & $11.2 \pm 2.3$ & 0.528 & $11.9 \pm 2.6$ & $11.3 \pm 2.4$ & $<0.001$ \\
\hline $\begin{array}{l}\text { Protein }{ }^{a, b} \\
\text { (\% of energy) }\end{array}$ & $17.9 \pm 3.6$ & $17.9 \pm 4.1$ & 0.869 & $17.5 \pm 3.2$ & $18.1 \pm 3.8$ & 0.131 & $17.9 \pm 3.8$ & $18.0 \pm 3.6$ & 0.576 \\
\hline $\begin{array}{l}\text { Dietary fiber, } \\
(\mathrm{g} / 1000 \mathrm{kcal})\end{array}$ & $9.1 \pm 3.0$ & $9.5 \pm 3.4$ & 0.395 & $10.6 \pm 4.2$ & $10.5 \pm 3.4$ & 0.797 & $9.2 \pm 3.1$ & $10.5 \pm 3.7$ & $<0.001$ \\
\hline $\begin{array}{l}\text { Total calcium intake } e^{\mathrm{a}, \mathrm{c}} \\
(\mathrm{mg})\end{array}$ & $1303.6 \pm 791.9$ & $1328.2 \pm 811.5$ & 0.874 & $1317.7 \pm 742.8$ & $1169 \pm 680.7$ & 0.017 & $1311.5 \pm 797.0$ & $1215.2 \pm 702.8$ & 0.086 \\
\hline $\begin{array}{l}\text { Calcium-to-protein } \\
\text { ratio }\end{array}$ & $11.1 \pm 3.7$ & $11.2 \pm 4.4$ & 0.830 & $12.0 \pm 3.6$ & $11.5 \pm 4.0$ & 0.130 & $11.2 \pm 3.9$ & $11.6 \pm 3.8$ & 0.048 \\
\hline $\begin{array}{l}\text { Dairy intake }{ }^{a, c} \\
\text { (servings/day) }\end{array}$ & $2.4 \pm 1.8$ & $2.3 \pm 2.1$ & 0.289 & $2.3 \pm 1.6$ & $2.0 \pm 1.6$ & 0.058 & $2.3 \pm 1.9$ & $2.1 \pm 1.6$ & 0.185 \\
\hline $\begin{array}{l}\text { Cheese }^{\mathrm{a}, \mathrm{c}} \\
\text { (servings/day) (\%) }\end{array}$ & $0.5 \pm 0.7$ & $0.5 \pm 0.7$ & 0.793 & $0.5 \pm 0.8$ & $0.4 \pm 0.6$ & 0.996 & $0.52 \pm 0.67$ & $0.46 \pm 0.66$ & 0.048 \\
\hline$<0.3$ serving/day & 57.9 & 59.7 & 0.753 & 71.0 & 65.8 & 0.247 & 58.5 & 67.3 & 0.007 \\
\hline$\geqslant 0.3$ serving $/$ day & 42.1 & 40.3 & & 29.0 & 34.2 & & 41.1 & 32.7 & \\
\hline
\end{tabular}

Abbreviations: WC, waist circumference; P90, 90th percentile. ${ }^{a}$ Mean \pm s.d. ${ }^{b}$ Between-gender and WC percentiles analysis by Student's $t$-test. ${ }^{~} B e t w e e n-g e n d e r$ and WC percentiles analysis by Mann-Whitney test. 


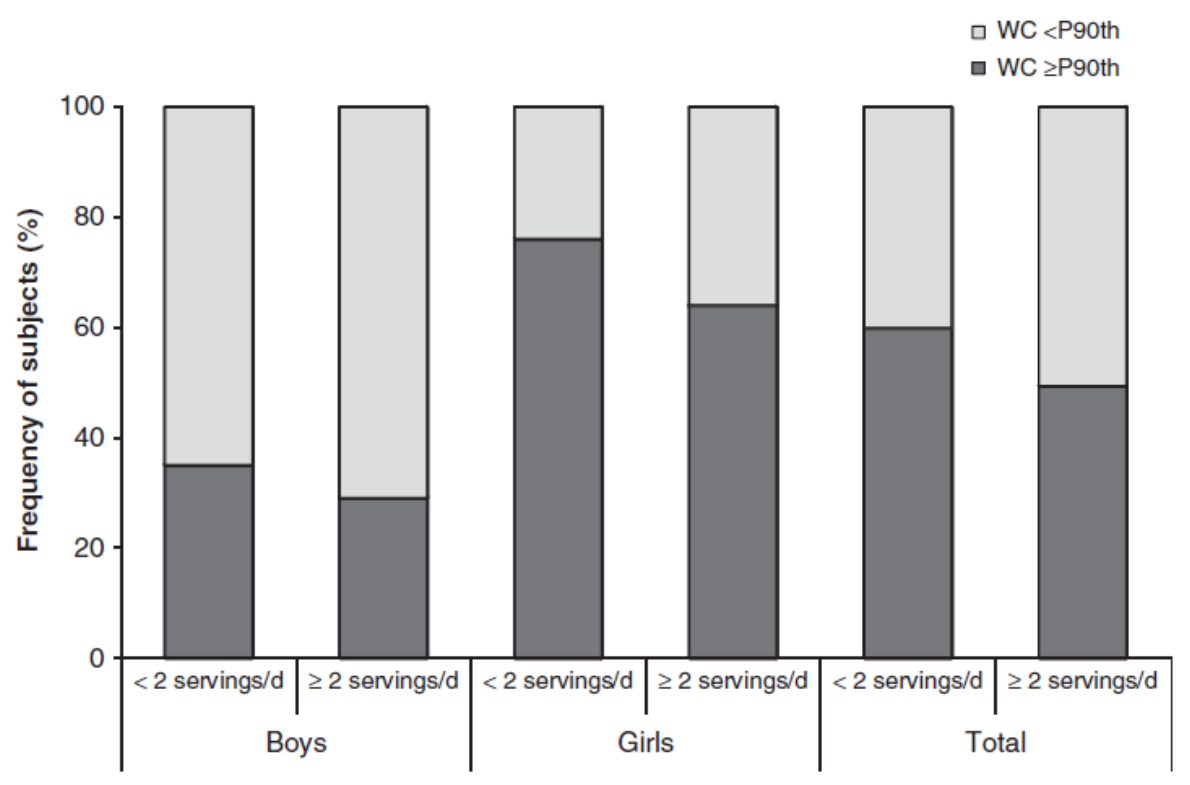

Figure 1. Distribution of subjects in dairy intake categories based on their WC.

it is noteworthy that the same finding for cheese consumption was only observed in NHANES III data. Regarding the beneficial role of different DPs on body fat, in children and adolescents, cross-sectional11,43 and longitudinal8,10,39 studies have shown an inverse association between milk and adiposity, but this association was not found in other studies.12,38 On the other hand, cheese consumption was only addressed in adults, $21,41,42$ and some of these studies 41,42 reported a positive association with prevalence of obesity and AO. Moreover, an inverse association between yogurt intake and adiposity was only shown in Beydoun's study. 41

Therefore, overall, the evidence suggests that milk and yogurt are associated with lower adiposity, with cheese having the opposite effect.14 In this study, we only analyzed the association between total milk and yogurt intake and $\mathrm{AO}$ (milk and yogurt when considered separately were not associated with AO; data not shown).

In agreement with our results, other studies have found a higher proportion of $A O$ in girls.1,2 Furthermore, the prevalence of

\begin{tabular}{|c|c|c|c|c|c|c|}
\hline & \multicolumn{3}{|c|}{ Boys $(\mathrm{n}=370)$} & \multicolumn{3}{|c|}{ Girls $(\mathrm{n}=533)$} \\
\hline & $O R$ & $95 \% \mathrm{Cl}$ & $\mathrm{P}$ & OR & $95 \% \mathrm{Cl}$ & $P$ \\
\hline Model 1 & 0.474 & $0.238-0.945$ & 0.034 & 0.545 & $0.355-0.839$ & 0.006 \\
\hline Model $2^{\mathrm{a}}$ & 0.217 & $0.075-0.633$ & 0.005 & 0.560 & $0.307-1.022$ & 0.059 \\
\hline Model $3^{\mathrm{b}}$ & 0.208 & $0.070-0.617$ & 0.005 & 0.563 & $0.307-1.032$ & 0.063 \\
\hline
\end{tabular}

AO has been increasing at a faster rate in girls than in boys.1,2 On the other hand, even after adjusting for confounders, there was a non-significant association between dairy consumption and AO in girls. There are several possible explanations for these findings.

WC is unlikely to be due to visceral adipose tissue alone; it probably reflects both visceral and subcutaneous fat. It is known that adult women have a greater amount of subcutaneous fat than men and less visceral fat, a difference closely related to gender differences in cardiometabolic disease risk. 44 -- 46 These differences begin early in life and become more apparent in puberty due to changes in sex hormone levels. However, studies on gender differences in visceral fat in adolescents have discrepant results. Some have suggested that boys have more visceral fat than girls,47,48 while others have found no significant differences.49 Nevertheless, it is important to note that this is one of few studies that addressed sexual maturation, controlling for the extent of biological growth and the individual nutritional needs of adolescents.50 
Several studies have suggested a beneficial effect of some dairy components, especially calcium, on weight and body fat loss. The plausible mechanism most frequently cited relates to the effects of calcium on adipocyte metabolism and fatty acid absorption from the gastrointestinal tract.14 Zemel 51,52 has demonstrated that the concentration of intracellular Cazp in human adipocyte is increased by the stimulation of parathyroid hormone and 1,25-dihydroxyvitamin $D_{3}$, which occurs in response to a lowcalcium diet. The resultant increase in intracellular $\mathrm{Ca} 2 \mathrm{p}$ exerts a coordinated effect on adipocyte lipid metabolism, serving to stimulate lipogenic gene expression and lipogenesis, thereby increasing lipid filling and adiposity. Calcium is also able to increase fecal excretion of fat via the formation of insoluble fatty acid soaps or by binding bile acids. 14 However, these mechanisms do not entirely explain the observed 'antiobesity' effects of DPs.53

Dairy is also an important source of proteins, and whey proteins have been positively associated with satiety.14 Moreover, it has been shown that whey protein inhibits angiotensin-converting enzyme and consequently inhibits the production of angiotensin II hormone,53 which has been reported to upregulate adipocyte lipogenesis, resulting in the inhibition of fat deposition.54 Yet, there is lack of knowledge concerning the mechanisms that explain the effects of DPs on the loss of central adiposity. Visceral adipose tissue has greater amounts of 11-b-HSD-1 (11-b-hidroxysteroid dehydrogenase), which can generate active cortisol from cortisone, than does subcutaneous adipose tissue. 55 In-vitro data obtained from mice suggest that the selective overexpression of 11-b-HSD-1 in adipose tissue results in central obesity.56 It has been suggested that a high-calcium and high-dairy diet may reduce cortisol production because visceral adipocytes stimulate lipolysis.55 Nevertheless, no studies have specifically examined these mechanisms in children and adolescents, and the dynamic metabolic changes that occur during growth and puberty may further complicate these issues.57 Furthermore, it is possible that the interaction between body fat and DPs depends not only on the threshold of percentage of body fat, 9 but also indeed on its distribution by gender, with boys having more visceral fat.

However, DP consumption may also be associated with dimensions of a healthier lifestyle that protect against adiposity, such as frequency of eating episodes.58,59

There are some limitations in our study that should be addressed. First, the cross-sectional design of this study prevents any conclusions related to cause and effect. Second, we did not include cheese in DPs, because the food frequency questionnaire was not specifically designed to account for different types of cheese, but we did control for the effects of cheese intake. Third, the measure of AO used in this study is an indirect estimate of abdominal fat. However, WC has been used as a simple anthropometric tool, to access and identify adolescents who are at risk of having AO. It has been suggested that WC is one of the most common proxy measures of $\mathrm{AO}_{1}$ and is strongly associated with visceral adipose tissue.60

In conclusion, we found that DPs have a protective effect on AO only in boys. These results suggest that DP intake may be related to body fat distribution. Future research, with more accurate measures of visceral adiposity, is needed to address this relationship and to examine the effects of different types of DPs.

\section{REFERENCES}

$1 \mathrm{Li} \mathrm{C}$, Ford ES, Mokdad AH, Cook S. Recent trends in waist circumference and waist-height ratio among US children and adolescents. Pediatrics 2006; 118, e1390 -- e1398.

2 McCarthy HD, Ellis SM, Cole TJ. Central overweight and obesity in British youth aged 11 - 16 years: cross sectional surveys of waist circumference. BMJ 2003; 326, 624.

3 Rudolf MC, Greenwood DC, Cole TJ, Levine R, Sahota P, Walker J et al. Rising obesity and expanding waistlines in schoolchildren: a cohort study. Arch Dis Child 2004; 89, 235 -- 237.

4 Moreno LA, Sarria A, Fleta J, Marcos A, Bueno M. Secular trends in waist circumference in Spanish adolescents, 1995 to 2000 -- 02. Arch Dis Child 2005; 90, 818 -- 819.

5 Bradlee ML, Singer MR, Qureshi MM, Moore LL. Food group intake and central obesity among children and adolescents in the Third National Health and Nutrition Examination Survey (NHANES III). Public Health Nutr 2010; 13, 797 -- 805.

6 Ritchie LD, Spector P, Stevens MJ, Schmidt MM, Schreiber GB, Striegel-Moore RH et al. Dietary patterns in adolescence are related to adiposity in young adulthood in black and white females. J Nutr 2007; 137, 399 -- 406.

7 Novotny R, Daida YG, Acharya S, Grove JS, Vogt TM. Dairy intake is associated with lower body fat and soda intake with greater weight in adolescent girls. J Nutr 2004; 134, 1905 -- 1909.

8 Carruth BR, Skinner JD. The role of dietary calcium and other nutrients in moderating body fat in preschool children. Int J Obes Relat Metab Disord 2001; 25, 559 -- 566.

9 Moreira P, Padez C, Mourao I, Rosado V. Dietary calcium and body mass index in Portuguese children. Eur J Clin Nutr 2005; 59 , 861 -867.

10 Moore LL, Bradlee ML, Gao D, Singer MR. Low dairy intake in early childhood predicts excess body fat gain. Obesity (Silver Spring) 2006; 14, $1010--1018$.

11 Moore LL, Singer MR, Qureshi MM, Bradlee ML. Dairy intake and anthropometric measures of body fat among children and adolescents in NHANES. J Am Coll Nutr 2008; 27, 702 -- 710.

12 Phillips SM, Bandini LG, Cyr H, Colclough-Douglas S, Naumova E, Must A. Dairy food consumption and body weight and fatness studied longitudinally over the adolescent period. Int J Obes Relat Metab Disord 2003; 27, 1106 -- 1113.

13 Huh SY, Rifas-Shiman SL, Rich-Edwards JW, Taveras EM, Gillman MW. Prospective association between milk intake and adiposity in preschool-aged children. J Am Diet Assoc 2010; 110, 563 -- 570

14 Dougkas A, Reynolds CK, Givens ID, Elwood PC, Minihane AM. Associations between dairy consumption and body weight: a review of the evidence and underlying mechanisms. Nutr Res Rev 2011; 24, 72--95.

15 Zemel MB, Thompson W, Milstead A, Morris K, Campbell P. Calcium and dairy acceleration of weight and fat loss during energy restriction in obese adults. Obes Res $2004 ; 12,582$-- 590.

16 Shi H, Dirienzo D, Zemel MB. Effects of dietary calcium on adipocyte lipid metabolism and body weight regulation in energy-restricted aP2-agouti transgenic mice. FASEB J 2001; 15, 291 -- 293.

17 Zemel MB. Mechanisms of dairy modulation of adiposity. J Nutr 2003; 133, 252S -- 256S.

18 US Department of Agriculture and US Department of Health and Human Services.Dietary Guidelines for Americans, 2010, 7th edn. US Government Printing Office: Washington, DC, 2010, p 16.

19 Marques-Vidal P, Goncalves A, Dias CM. Milk intake is inversely related to obesity in men and in young women: data from the Portuguese Health Interview Survey 1998 -- 1999. Int J Obes (Lond) 2006; 30, 88--93. 
20 Pereira MA, Jacobs Jr DR, Van Horn L, Slattery ML, Kartashov AI, Ludwig DS. Dairy consumption, obesity, and the insulin resistance syndrome in young adults: the CARDIA study. JAMA 2002; 287, 2081 -- 2089.

21 Rosell M, Hakansson NN, Wolk A. Association between dairy food consumption and weight change over 9 y in 19352 perimenopausal women. Am J Clin Nutr 2006; 84, 1481 -- 1488

22 Vergnaud AC, Peneau S, Chat-Yung S, Kesse E, Czernichow S, Galan P et al. Dairy consumption and 6-y changes in body weight and waist circumference in middleaged French adults. Am J Clin Nutr 2008; 88, 1248 -- 1255.

23 Zemel MB, Richards J, Milstead A, Campbell P. Effects of calcium and dairy on body composition and weight loss in African-American adults. Obes Res 2005; 13, 1218 -- 1225

24 Instituto Nacional Estatı́stica. Estimativas da Populac,ão Residente, segundo Grandes Grupos Etários e Sexo 2003 [cited November 2008]; Available from: http:// www.ine.pt/.

25 Cole TJ, Bellizzi MC, Flegal KM, Dietz WH. Establishing a standard definition for child overweight and obesity worldwide: international survey. BMJ 2000; 320, 1240 -- 1243.

26 McCarthy HD, Jarrett KV, Crawley HF. The development of waist circumference percentiles in British children aged 5.0 -- 16.9 y. Eur J Clin Nutr 2001; 55, 902 -- 907.

27 Zimmet P, Alberti KG, Kaufman F, Tajima N, Silink M, Arslanian S et al. The metabolic syndrome in children and adolescents - an IDF consensus report. Pediatr Diabetes 2007; 8, 299 -- 306.

28 Tanner JM, Whitehouse RH. Clinical longitudinal standards for height, weight, height velocity, weight velocity, and stages of puberty. Arch Dis Child 1976; 51, 170--179.

29 World Health Organization. Guidelines for Controlling and Monitoring the Tobacco Epidemic. WHO: Geneva, 1998.

30 Ramos E. Health Determinants in Porto Adolescents - The Epiteen Cohort. University of Porto: Porto, 2006.

31 Willett W. Food frequency methods Nutritional Epidemiology 2nd edn. Oxford University Press: New York, 1998, pp. 74 -- 100.

32 Rodrigues SS, Franchini B, Graca P, de Almeida MD. A new food guide for the Portuguese population: development and technical considerations. J Nutr Educ Behav 2006; 38, 189 -- 195.

33 Davies KM, Heaney RP, Recker RR, Lappe JM, Barger-Lux MJ, Rafferty K et al. Calcium intake and body weight. J Clin Endocrinol Metab 2000; 85, 4635 -- 4638.

34 Church CF. Bowes and Church's Food Values of Portions Commonly Used. Lippincott: Philadelphia, 1975.

35 Telama R, Yang X, Laakso L, Viikari J. Physical activity in childhood and adolescence as predictor of physical activity in young adulthood. Am J Prev Med 1997; 13, 317 -- 323

36 Mota J, Esculcas C. Leisure-time physical activity behavior: structured and unstructured choices according to sex, age, and level of physical activity. Int J Behav Med 2002; 9, 111 -- 121.

37 Halkjaer J, Tjonneland A, Overvad K, Sorensen TI. Dietary predictors of 5-year changes in waist circumference. J Am Diet Assoc 2009; $109,1356-1366$.

38 Berkey CS, Rockett HR, Willett WC, Colditz GA. Milk, dairy fat, dietary calcium, and weight gain: a longitudinal study of adolescents. Arch Pediatr Adolesc Med 2005; 159, 543 -- 550.

39 Striegel-Moore RH, Thompson D, Affenito SG, Franko DL, Obarzanek E, Barton BA et al. Correlates of beverage intake in adolescent girls: the National Heart, Lung, and Blood Institute Growth and Health Study. J Pediatr 2006; 148, 183 -- 187.

40 Louie JC, Flood VM, Hector DJ, Rangan AM, Gill TP. Dairy consumption and overweight and obesity: a systematic review of prospective cohort studies. Obes Rev 2011; 12, e582 -- e592.

41 Beydoun MA, Gary TL, Caballero BH, Lawrence RS, Cheskin LJ, Wang Y. Ethnic differences in dairy and related nutrient consumption among US adults and their association with obesity, central obesity, and the metabolic syndrome. Am J Clin Nutr 2008; 87,1914 -- 1925. 42 Snijder MB, van der Heijden AA, van Dam RM, Stehouwer CD, Hiddink GJ, Nijpels G et al. Is higher dairy consumption associated with lower body weight and fewer metabolic disturbances? the Hoorn study. Am J Clin Nutr 2007; 85, 989 -- 995.

43 Barba G, Troiano E, Russo P, Venezia A, Siani A. Inverse association between body mass and frequency of milk consumption in children. Br J Nutr 2005; 93, 15--19.

44 Regitz-Zagrosek V, Lehmkuhl E, Weickert MO. Gender differences in the metabolic syndrome and their role for cardiovascular disease. Clin Res Cardiol 2006; 95, 136 -- 147.

45 Jousilahti $P$, Vartiainen E, Tuomilehto J, Puska P. Sex, age, cardiovascular risk factors, and coronary heart disease: a prospective follow-up study of 14786 middle-aged men and women in Finland. Circulation 1999; 99, 1165 -- 1172.

46 Lemieux S, Prud'homme D, Bouchard C, Tremblay A, Despres JP. Sex differences in the relation of visceral adipose tissue accumulation to total body fatness. Am J Clin Nutr 1993; 58, 463 -- 467.

47 Lee S, Kuk JL, Hannon TS, Arslanian SA. Race and gender differences in the relationships between anthropometrics and abdominal fat in youth. Obesity (Silver Spring) 2008; 16, 1066 -- 1071.

48 Syme C, Abrahamowicz M, Leonard GT, Perron M, Pitiot A, Qiu X et al. Intraabdominal adiposity and individual components of the metabolic syndrome in adolescence: sex differences and underlying mechanisms. Arch Pediatr Adolesc Med 2008; 162,453 -- 461.

49 Shen W, Punyanitya M, Silva AM, Chen J, Gallagher D, Sardinha LB et al. Sexual dimorphism of adipose tissue distribution across the lifespan: a cross-sectional whole-body magnetic resonance imaging study. Nutr Metab (Lond) 2009; 6, 17.

50 Stang J, Story M. Adolescent growth and development. In: Guidelines for adolescent nutrition services (ed). Center for Leadership, Education and Training in Maternal and Child Nutrition, Division of Epidemiology and Community Health, School of Public Health, University of Minnesota: Minneapolis, MN, 2005, pp. 1 -- 8.

51 Zemel MB. Role of calcium and dairy products in energy partitioning and weight management. Am J Clin Nutr 2004; 79, 907S -- 912S.

52 Zemel MB. Role of dietary calcium and dairy products in modulating adiposity. Lipids 2003; 38, 139 -- 146.

53 Zemel MB. The role of dairy foods in weight management. J Am Coll Nutr 2005; 24 (6 Suppl), 537S -- 546S.

54 Huth PJ, DiRienzo DB, Miller GD. Major scientific advances with dairy foods in nutrition and health. J Dairy Sci $2006 ; 89,1207$-- 1221.

55 Morris KL, Zemel MB. 1,25-dihydroxyvitamin D3 modulation of adipocyte glucocorticoid function. Obes Res 2005; 13, 670 -- 677.

56 Masuzaki H, Paterson J, Shinyama H, Morton NM, Mullins JJ, Seckl JR et al. A transgenic model of visceral obesity and the metabolic syndrome. Science $2001 ; 294,2166--2170$

57 Huang TT, McCrory MA. Dairy intake, obesity, and metabolic health in children and adolescents: knowledge and gaps. Nutr Rev 2005; $63,71-80$.

58 Barba G, Troiano E, Russo P, Siani A. Total fat, fat distribution and blood pressure according to eating frequency in children living in southern Italy: the ARCA project. Int J Obes (Lond) 2006; 30, 1166 -- 1169

59 Rodriguez G, Moreno LA. Is dietary intake able to explain differences in body fatness in children and adolescents? Nutr Metab Cardiovasc Dis 2006; 16, 294-- 301

60 de Koning L, Merchant AT, Pogue J, Anand SS. Waist circumference and waist-tohip ratio as predictors of cardiovascular events: metaregression analysis of prospective studies. Eur Heart J 2007; 28, 850 -- 856. 